
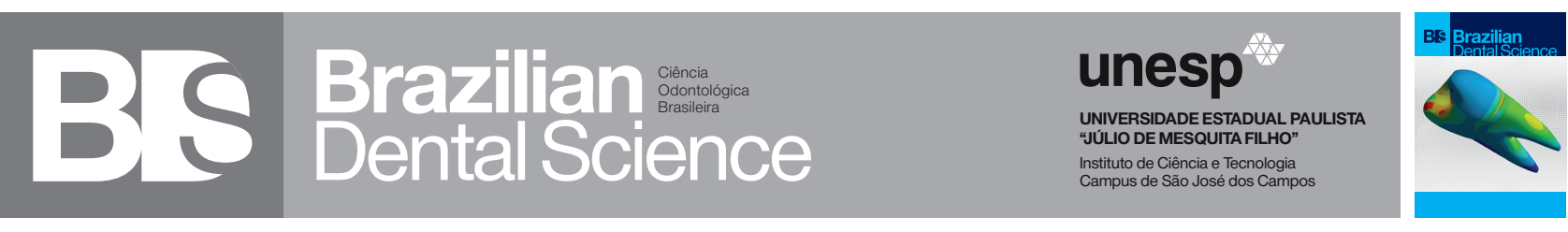

\title{
Scaffold architecture for dental biomaterials: influence of process parameters on the structural morphology of chitosan electrospun fibers
}

Arquitetura de arcabouços para biomateriais: influência dos parâmetros do processo na morfologia estrutural de fibras de quitosana eletrofiadas

\author{
Joyce Rodrigues de SOUZA ${ }^{1}$, Tabata Prado SATO $^{2}$, Alexandre Luiz Souto BORGES ${ }^{2}$ \\ 1 - São Paulo State University (Unesp) - Institute of Science and Technology - SãoJosé dos Campos - SP - Brazil. \\ 2 - São Paulo State University (Unesp) - Institute of Science and Technology - São José dos Campos - Department of Dental Materials and \\ Prosthodontics - SP - Brazil.
}

\begin{abstract}
Objectives: The electrospinning is a widely adopted technique used to produce the polymeric fibers. The process depends on process parameters (voltage, flow rate and distance from capillary to the collector). The present study aimed to evaluate the influence of these parameters on chitosan fibers, a biopolymer used as scaffolds in dental and oral tissue engineering. Material and Methods: A solution of $7 \%(\mathrm{~m} / \mathrm{w})$ was prepared dissolving $0.7 \mathrm{~g}$ of chitosan in $7 \mathrm{~mL}$ of trifluoroacetic acid (TFA) and $0.3 \mathrm{~mL}$ of dichloromethane (DCM) (TFA/DCM - 70:30). After 12 hours, polymer solution $(5 \mathrm{~mL})$ was drawn into the syringe and pumped through needles of $0.4 \mathrm{~mm}$ internal diameter, at a rate of $0.8 \mathrm{mLh}^{-1}$, different needle-tip-to-collector distances and voltages, for $10 \mathrm{~min}$. Electrospun fibers micrographies were obtained using the Scanning Electron Microscope for morphological analysis. Results:All voltages showed significant difference ( $p<0.0001$ ) between them. At $15 \mathrm{kV}$ fibers showed higher concentration of beads. At 10 and $12 \mathrm{~cm}$ of distance there was no statistical significance (p $>0.0001$ ) but at $15 \mathrm{~cm}$ beads formation increased significantly ( $\mathrm{p}<0.0001)$. At $12 \mathrm{~cm}$ fibers showed lowest fibers diameter in comparison to 10 and $15 \mathrm{~cm}$ ( $p<0.0001)$. There was no difference between 10 and $12 \mathrm{~cm}(\mathrm{p}>0.0001)$ but in comparison to $15 \mathrm{~cm}$ both distances presented significantly difference ( $p$ $<0.0001$ ). Conclusion: Thus, it can be concluded that morphology, in chitosan electrospun fibers, is influenced by the voltage and distance and this could describe the mohphological control of these structures.
\end{abstract}

\section{KEYWORDS}

Chitosan; Fibers; Electrochemical.

\section{RESUMO}

Objetivo: A eletrofiação é uma técnica amplamente adotada para produzir fibras poliméricas. $\mathrm{O}$ processo depende dos parâmetros do processo (tensão elétrica, razão de fluxo e distância do capilar ao coletor). O presente estudo teve como objetivo avaliar a influência desses parâmetros sobre fibras de quitosana, um biopolímero utilizado como arcabouçosna engenharia de tecidos dentários and orais. Material e Métodos: Uma solução de $7 \%(\mathrm{~m} / \mathrm{w})$ foi preparada dissolvendo $0,7 \mathrm{~g}$ de quitosana em $7 \mathrm{~mL}$ de ácido trifluoroacético (TFA) e 0,3 mL de diclorometano (DCM) (TFA / DCM - 70:30). Após 12 horas, a solução (5 mL) foi colocada em uma seringa e bombeada através de agulhas de 0,4 mm de diâmetro, sob uma taxa de $0,8 \mathrm{mLh}^{-1}$, diferentes distâncias e tensões, por 10 min. Micrografias de fibras eletrofiadas foram obtidas usando o Microscópio Eletrônico de Varredura para análise morfológica. Resultados: Todas as tensões apresentaram diferença significativa $(p<0,0001)$ entre elas. Sob $15 \mathrm{kV}$ fibras apresentaram maior concentração de grânulos. Sob 10 e $12 \mathrm{~cm}$ de distância não houve significância estatística ( $>0,0001$ ), mas sob $15 \mathrm{~cm}$ os grânulos aumentaram significativamente $(\mathrm{p}<0,0001)$. Com $12 \mathrm{~cm}$ as fibras de quitosana apresentarammenor diâmetro em comparação às de 10 e $15 \mathrm{~cm}(\mathrm{p}<0,0001)$. Não houve diferença entre 10 e $12 \mathrm{~cm}$ ( $p>0,0001)$, mas em comparação com $15 \mathrm{~cm}$, ambas as distâncias apresentaram diferença significativa ( $p<0,0001)$. Conclusão: Assim, podese concluir que a morfologia das fibras eletrofiadas de quitosana é influenciada pela tensão elétrica e distância, descrevendo o controle morfológico dessas estruturas.

\section{PALAVRAS-CHAVE}

Quitosana; Fibras; Eletroquímica. 


\section{INTRODUCTION}

$\mathrm{T}$ he electrospinning is a widely adopted technique used to produce polymeric nanofibers [1].These materials have different mechanical, electrical and thermal propertiesfunctionality [2], and demonstrate potential in many areas, with important structural characteristics for applications in biological systems $[3,4]$.

These applications are facing the challenges of regenerative strategies that use scaffolds to provide a surface on which cells may adhere, grow, and form an organized arrangement according to tissue complexity, such as dental and oral structures $[5,6]$.

In this sense, chitosan scaffolds appear to be suitable for a variety applications. Chitosan, is a biopolymer used in the medical and pharmaceutical area, obtained from the deacetylation of chitin[7], that is widely studied because of its characteristics, such as antimicrobial activity [8], analgesic effect [9] and biodegradability $[7,10,11]$.

A currently available technique for nanofiber synthesis is the electrospinning [12] that, essentially, consists of a capillary containing polymer solution, a high voltage source and a conductive collector.

The high voltage source is responsible for creating an electric field that will act on the surface of a polymer solution producing liquid jet ejection, which generates solid fibers during the solvent-evaporation process $[13,14]$.

The process depends on parameters of solution (viscosity; superficial tension and conductivity and type of polymer], of the process (voltage, flow rate and distance from capillary to the collector)and environmental (humidity and temperature) $[15,16]$, as can be seen in Figure 1.

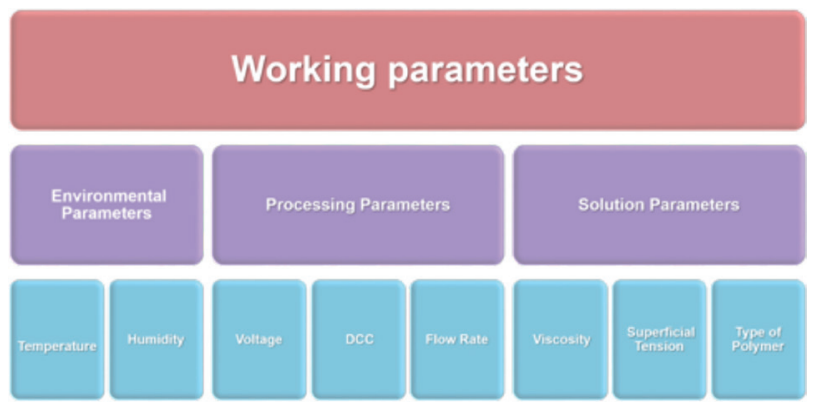

Figure 1 - Working parameters of electrospun nanofibers synthesis

From this, electrospun fibers commonly reported discontinuities, called beads [17], related in some studies to the instabilities of the polymer solution jet $[18,19]$.

Often considered as a defect in fiber morphology, the formation of granules is strongly influenced by several parameters, some already mentioned, such as process and solution parameters $[20,21]$.

Thus, the aim of the present study was to evaluate the influence of electrospinning parameters on chitosanfibers to characterizethe scaffolds architecture for guided tissue regeneration.

\section{MATERIAL AND METHODS}

Table 1- Materials used in the study according to manufacturer's information

\begin{tabular}{|cccc}
\hline Material & Manufacturer & Composition & Lot\# \\
\hline Chitosan & $\begin{array}{c}\text { Sigma-Aldrich, } \\
\text { SaintLouis, USA }\end{array}$ & $\mathrm{C}_{6} \mathrm{H}_{11} \mathrm{O}_{4} \mathrm{~N}$ & SLBH2747V \\
\hline $\begin{array}{c}\text { Trifluoroacetic } \\
\text { Acid }\end{array}$ & $\begin{array}{c}\text { Sigma-Aldrich, } \\
\text { SaintLouis, USA }\end{array}$ & $\mathrm{C}_{2} \mathrm{HF}_{3} \mathrm{O}_{2}$ & SHBF6609V \\
$\begin{array}{c}\text { Dichlorome- } \\
\text { thane }\end{array}$ & $\begin{array}{c}\text { Sigma-Aldrich, } \\
\text { SaintLouis, USA }\end{array}$ & $\mathrm{CH}_{2} \mathrm{Cl}_{2}$ & STBF0286V \\
\hline
\end{tabular}

\section{Solution Preparation}

A solution of $7 \%(\mathrm{~m} / \mathrm{w})$ was prepared dissolving $0.7 \mathrm{~g}$ of medium molecular weight chitosan (Sigma-Aldrich) in $7 \mathrm{~mL}$ of trifluoroacetic acid (TFA) (Sigma-Aldrich) and $0.3 \mathrm{~mL}$ of 
dichloromethane (DCM) (Sigma-Aldrich, Saint Louis, USA) (TFA/DCM - 70:30).

Initially, the chitosan was dissolved gradually as TFA by placing the assembly in a shaker (IKA RH Basic, Staufen, Germany), at room temperature. Then DCM was added gradually.

\section{Electrospinning}

After 12 hours, polymer solution $(5 \mathrm{~mL})$ was placed in the syringe and pumped through needles of $0.4 \mathrm{~mm}$ internal diameter, ata rate of $0.8 \mathrm{mLh}^{-1}$, for $10 \mathrm{~min}$ anddifferent needle-tipto-collector distances and voltages, as shown in Table 2 .

Table 2 - Parameters used for electrospinning

\begin{tabular}{ccccc}
\multicolumn{1}{c}{ Samples } & \multicolumn{3}{c}{ Voltage } \\
& $10 \mathrm{~cm}$ & A & D & G \\
\hline \multirow{2}{*}{ Distance } & $12 \mathrm{~cm}$ & B & E & H \\
& $15 \mathrm{~cm}$ & C & F & I
\end{tabular}
(SEM)

Analysis Scanning Electron Microscope

Electrospun nanofibers micrographies were obtained using the Scanning Electron Microscope with high-vacuum equipment (Inspect $S$ 50, FEI Company, Brno, Czech Republic) operating at $20-25 \mathrm{kV}, 5.0$ spot and magnifications of 1000 , 2000 and 5000x.

\section{Mean diameter and beads formation}

Mean diameter and beads formation of nanofibers were analyzed using the ImageJ image analysis software (Version 1.44o, National Public of Health) with micrographies obtained from the SEM, that were divided into 12 frames (Figure 2).

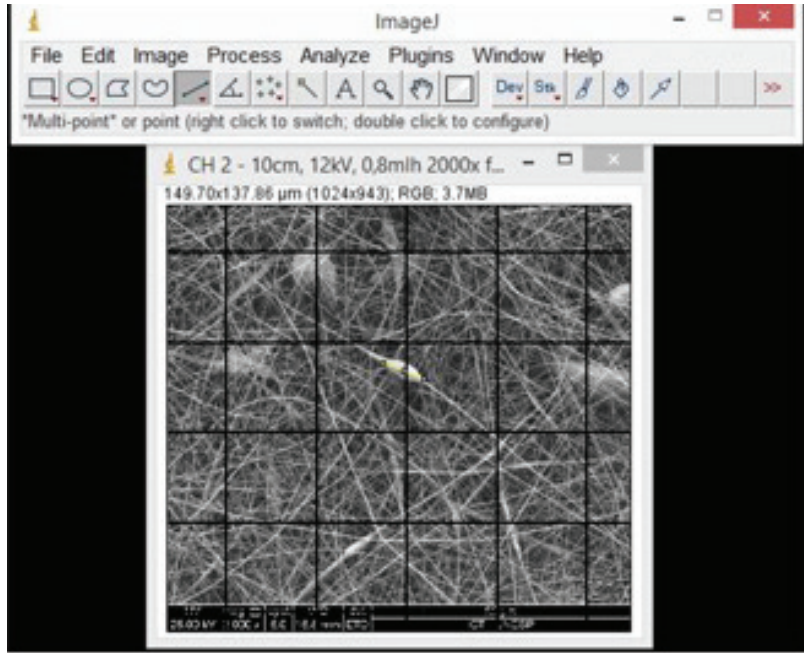

Figure 2 - Image analysis for accounting beads

\section{Statistical Analysis}

Two-way analysis of variance (ANOVA) was used to determine working parameters effects on mean diameter and beads formation.

\section{RESULTS}

SEM analysis is presented in Figure 3.

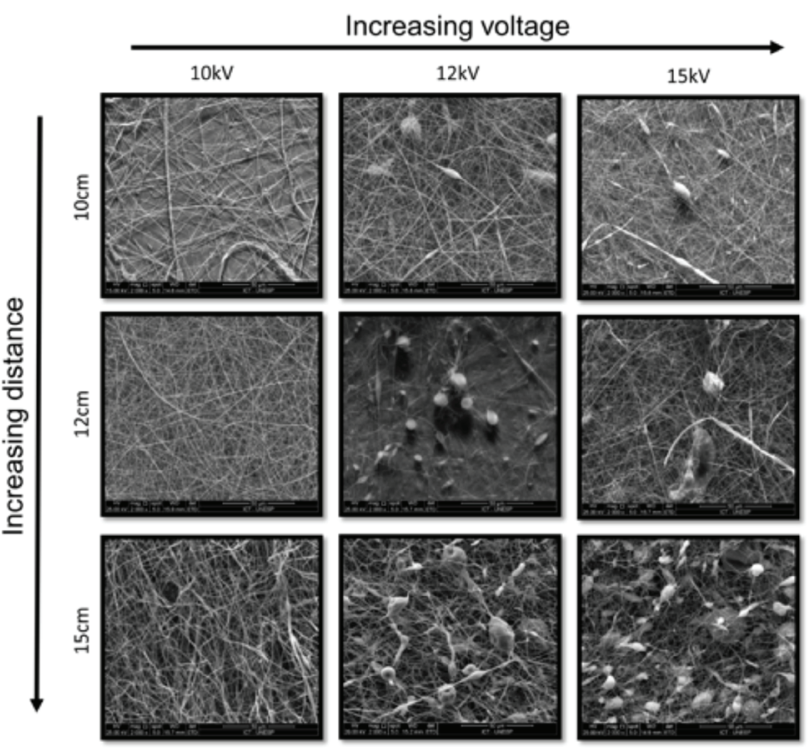

Figure 3 - SEM images of the fibers under different experimental conditions 
From this figure, it is clear that there is a tendency to bead formation at higher voltages.

These beads were statistically analyzed as shown on Figure 4.

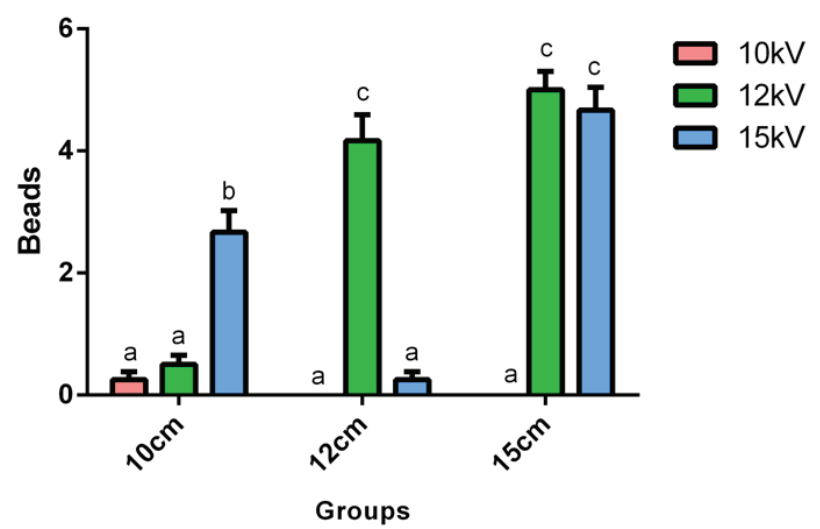

Figure 4 - Bar graph profile showing beads formulations

Voltage presented influence on beads formation. All voltages showed significant difference ( $p<0.0001$ ) between them. At $15 \mathrm{kV}$ fibers showed higher concentration of beads.

At 10 and $12 \mathrm{~cm}$ of distance between electrospinning tip and collector there is no statistical significance $(\mathrm{p}>0.0001)$ but at 15 $\mathrm{cm}$ beads formation increased significantly $(\mathrm{p}<$ 0.0001).

Fiber diameters measured by image analysis software (mean and standard deviations) and subsequent statistical analysis are presented in Figure 5.

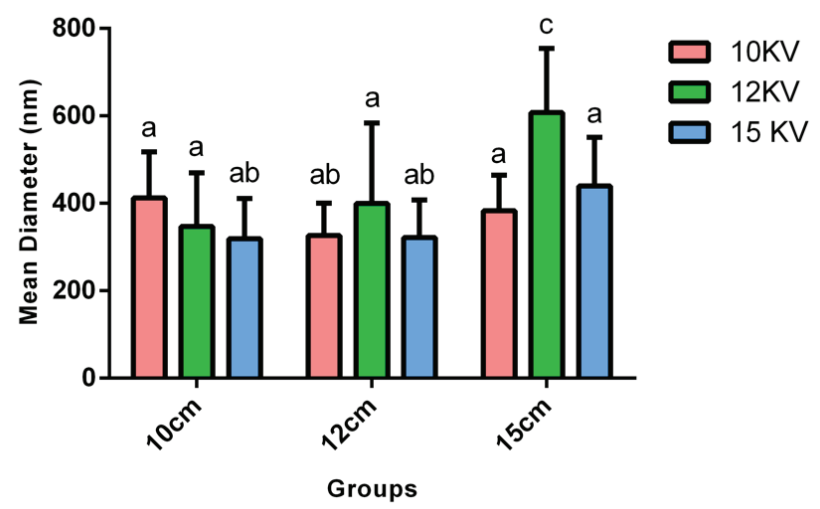

At $12 \mathrm{~cm}$ fibers showed lowest fibers diameter in comparison to 10 and $15 \mathrm{~cm} \mathrm{(p} \mathrm{<}$ 0.0001).

Distance influenced the fiber diameter. There is no difference between 10 and $12 \mathrm{~cm}$ ( $p>0.0001$ ) but in comparison to $15 \mathrm{~cm}$ both distances presented significantly difference $(\mathrm{p}<$ 0.0001).

\section{DISCUSSION}

Scaffolds for tissue engineering has been employed in intraoral applications such as periodontal and peri-implant regenerative medicine, oral and maxillofacial reconstructive surgery [22-24].

Thus, it is important to characterize the morphology structure of these materials. In this paper, it is shown the influence of electrospinning process parameters on chitosan scaffolds.

There is no consensus regarding theapplied voltages influenceon diameter of electrospun fiber. Some studies showed that electric field has no influence on the diameter fibers[25]. However, several groups suggested that higher voltages can increase the electrostatic repulsive force on the charged jet, favoring the narrowing of fiber diameter[26].

In this study, higher voltages (12 and 15 $\mathrm{kV})$, at $10 \mathrm{~cm}$, promoted significant diameter decrease. And, under 12 and $15 \mathrm{~cm}$, respectively, the $12 \mathrm{kV}$ presented the lowest diameters.

In this context, the needle-tip-to-collector distance can also affect the fiber diameter [27]. According to some studies, short distances do not promote enough time to fibers solidify before reaching the collector, whereas at long distances, beads formation can be presented[26,28].

In this sense, this study presented results that corroborate with previous studies and showed lowest diameters, for chitosan fibers,at $10 \mathrm{~cm}$ and higher beads formation at $15 \mathrm{~cm}$.

Figure 5 - Mean diameter (with SD) of nanofibers 
The beads formation was observed in the electrospinning process [29]considered as focal defects of electrospun fibers [30]attributed to different causes such as lower surface tension[30], higher voltage [31,32], viscosity solution [33] and polymer concentration [21, 34].Thus, the hypothesis was raised that with the voltage increase there is a form change of the solution surface from which the electrospinning jet originates, resulting alterations of the nanofibers morphology [12].

Also it was observed that the intensity of the electric voltage applied to the electrospinning can change the shape of the Taylor cone at the tip of the syringe, increasing and modifying beads formation[19]. This result agrees with the results of the present study, which found that higher voltages (12 and $15 \mathrm{kV}$ ] showed a significant increase of beads formation.

This can also related to the flow rate and voltage together. Some study showed that If one of these two parameters is changed alone beads can be formed[35].

Thus, these results suggest that electrospinning parameters influence the scaffold morphology.

\section{CONCLUSION}

It can be concluded that electrospinning parameters influenced the structural morphology of chitosan electrospun fibers and this is important for optimization research of oral mucosal regenerative biomaterials. The further biological characterization of chitosan nanofibers will support the development of this promising biomaterial into a successful tissue-engineering scaffold.

\section{REFERENCES}

1. Schmatz DA, da Silva Uebel L, Kuntzler SG, Dora CL, Vieira Costa JA, de Morais MG. Scaffolds Containing Spirulina sp. LEB 18 Biomass: Development, Characterization and Evaluation of In Vitro Biodegradation. J Nanosci Nanotechnol. 2016 Jan;16(1):1050-9.

2. Weiss J, Takhistov P, McClements DJ. Functional materials in food nanotechnology. JFood Sci. 2006;71(9):107-16.

3. Huang Z-M, Zhang YZ, Kotaki M, Ramakrishna S. A review on polymer nanofibers by electrospinning and their applications in nanocomposites. Comp Sci Tech. 2003;63(15):2223-53.

4. Greiner A, Wendorff JH. Electrospinning: a fascinating method for the preparation of ultrathin fibers. Angew Chem Int Ed Engl. 2007;46(30):5670-703.

5. Moioli EK, Clark PA, Xin X, Lal S, Mao JJ. Matrices and scaffolds for drug delivery in dental, oral and craniofacial tissue engineering. Adv Drug Deliv Rev. 2007 May 30;59(4-5):308-24. Epub 2007 Apr 18.

6. Galler KM, D'souza R, Hartgerink J, Schmalz G. Scaffolds for dental pulp tissue engineering. Adv Dent Res. 2011 Jul;23(3):333-9. doi: 10.1177/0022034511405326

7. Rinaudo M. Chitin and chitosan: properties and applications. ProgPolym Sci. 2006;31(7):603-32.

8. Silva HSRC, Santos KSCRd, Ferreira El. Quitosana: derivados hidrossolúveis, aplicações farmacêuticas e avanços. Química Nova. 2006;29:776-85.

9. Okamoto Y, Kawakami K, Miyatake K, Morimoto M, Shigemasa Y, Minami S. Analgesic effects of chitin and chitosan. Carbohy Polym. 2002:49(3):249-52.

10. Muzzarelli RA, Mattioli-Belmonte M, Pugnaloni A, Biagini G. Biochemistry, histology and clinical uses of chitins and chitosans in wound healing. EXS. 1999;87:251-64.

11. Ilium L. Chitosan and its use as a pharmaceutical excipient. Pharm Res. 1998 Sep;15(9):1326-31.

12. Agarwal S, Wendorff JH, Greiner A. Use of electrospinning technique for biomedical applications. Polymer. 2008;49(26):560321.

13. Ahmed FE, Lalia BS, Hashaikeh R. A review on electrospinning for membrane fabrication: challenges and applications. Desalination. 2015;356:15-30.

14. Lyons J, Li C, Ko F. Melt-electrospinning part I: processing parameters and geometric properties. Polymer. 2004;45(22):7597603.

15. Doshi J, Reneker DH. Electrospinning process and applications of electrospun fibers. J Electrostat. 1995;35(2-3):151-60.

16. Haider A, Haider S, Kang I-K. A comprehensive review summarizing the effect of electrospinning parameters and potential applications of nanofibers in biomedical and biotechnology. Arab J Chem. 2015. 
17. Vollrath F, Edmonds DT. Modulation of the mechanical properties of spider silk by coating with water. Nature. 1989 Jul;340:305-7.

18. Yarin AL. Free liquid jets and films. Hydrodynamics and Rheology. London. Longman Scientific \& Technical. 1993.

19. Entov V, Shmaryan L. Numerical modeling of the capillary breakup of jets of polymeric liquids. Fluid dynamics. 1997;32(5):696-703.

20. Lee K, Kim H, Bang H, Jung Y, Lee S. The change of bead morphology formed on electrospun polystyrene fibers. Polymer. 2003;44(14):4029-34.

21. Deitzel J, Kleinmeyer J, Harris D, Tan NB. The effect of processing variables on the morphology of electrospun nanofibers and textiles. Polymer. 2001;42(1):261-72

22. Izumi K, Feinberg S, lida A, Yoshizawa M. Intraoral grafting of an ex vivo produced oral mucosa equivalent: a preliminary report. Int $J$ Oral Maxillofac Surg. 2003 Apr;32(2):188-97.

23. Izumi K, Feinberg SE, Terashi H, Marcelo CL. Evaluation of transplanted tissue-engineered oral mucosa equivalents in severe combined immunodeficient mice. Tissue Eng. 2003 Feb;9(1):163-74.

24. Moharamzadeh K, Brook I, Van Noort R, Scutt A, Thornhill M. Tissue-engineered oral mucosa: a review of the scientific literature. J Dent Res. 2007 Feb;86(2):115-24.

25. Reneker $\mathrm{DH}$, Chun I. Nanometre diameter fibres of polymer, produced by electrospinning. Nanotechnology. 1996;7(3):216

26. Yuan X, Zhang Y, Dong C, Sheng J. Morphology of ultrafine polysulfone fibers prepared by electrospinning. Polymer International. 2004;53(11):1704-10.
27. Ki CS, Baek DH, Gang KD, Lee KH, Um IC, Park YH. Characterization of gelatin nanofiber prepared from gelatin-formic acid solution. Polymer. 2005;46(14):5094-102.

28. Li Z, Wang C. One-Dimensional nanostructures: Electrospinning Technique and Unique Nanofibers: Springer Berlin Heidelberg; 2013.

29. Miyoshi T, Toyohara K, Minematsu H. Preparation of ultrafine fibrous zein membranes via electrospinning. Polymer Int. 2005;54(8):1187-90.

30. Liu Y, He JH, Yu Jy, Zeng Hm. Controlling numbers and sizes of beads in electrospun nanofibers. Polymer Int. 2008;57(4):632-6.

31. Demir MM, Yilgor I, Yilgor E, Erman B. Electrospinning of polyurethane fibers. Polymer. 2002;43(11):3303-9.

32. Chang F-C, Chan K-K, Chang C-Y. The effect of processing parameters on formation of lignosulfonate fibers produced using electrospinning technology. BioResources. 2016;11(2):4705-17.

33. Zhang Y, Ouyang H, Lim CT, Ramakrishna S, Huang ZM. Electrospinning of gelatin fibers and gelatin/PCL composite fibrous scaffolds. J Biomed Mater Res B Appl Biomater. 2005 Jan 15;72(1):156-65.

34. Eda G, Shivkumar S. Bead-to-fiber transition in electrospun polystyrene. J Appl Polymer Sci. 2007;106(1):475-87.

35. Rodoplu D, Mutlu M. Effects of electrospinning setup and process parameters on nanofiber morphology intended for the modification of quartz crystal microbalance surfaces. JEng Fib Fab. 2012;7(2):118-23.

\section{Tabata Prado Sato}

\section{(Corresponding address)}

Av. Dr. Eng.Francisco Jose Longo, 777, Jd. Sao Dimas

Sao Jose dos Campos, Brazil

Email: tabata.sato@ict.unesp.br

Date submitted: 2017 0ct 23

Accept submission: 2017 Dec 06 